Sociology for Social Work 
Also by Lena Dominelli

Community Action: Organising Marginalised Groups

Love and Wages: The Impact of Imperialism, State intervention and Women's Domestic Labour on Workers' Control in Algeria, 1962-1972

Anti-Racist Social Work

Feminist Social Work

Women and Community Action

Women Across Continents: Feminist Comparative Social Policy

Gender, Sex Offenders and Probation Practice

Getting Advice in Urdu

Anti-Racist Social Work Education: Models for Practice

Anti-Racist Probation Practice 


\section{Sociology for Social Work}

Lena Dominelli

Consultant editor: Jo Campling 


\section{$\approx$}

(C) Lena Dominelli 1997

All rights reserved. No reproduction, copy or transmission of this publication may be made without written permission.

No paragraph of this publication may be reproduced, copied or transmitted save with written permission or in accordance with the provisions of the Copyright, Designs and Patents Act 1988, or under the terms of any licence permitting limited copying issued by the Copyright Licensing Agency, 90 Tottenham Court Road, London W1P 9HE.

Any person who does any unauthorised act in relation to this publication may be liable to criminal prosecution and civil claims for damages.

The author has asserted her rights to be identified as the author of this work in accordance with the Copyright, Designs and Patents Act 1988.

First published 1997 by MACMILLAN PRESS LTD

Houndmills, Basingstoke, Hampshire RG21 6XS

and London

Companies and representatives

throughout the world

ISBN 978-0-333-61521-8 ISBN 978-1-349-13473-1 (eBook)

DOI 10.1007/978-1-349-13473-1

A catalogue record for this book is available from the British Library.

This book is printed on paper suitable for recycling and made from fully managed and sustained forest sources.

$\begin{array}{cccccccccc}10 & 9 & 8 & 7 & 6 & 5 & 4 & 3 & 2 & 1 \\ 06 & 05 & 04 & 03 & 02 & 01 & 00 & 99 & 98 & 97\end{array}$

Editing and origination by Aardvark Editorial, Suffolk 
To Nazareno, Salvatore, Nicola, David and Nicholas 


\section{Contents}

INTRODUCTION

A sociological connection 2

Sociology's relevance to social work 5

The structure of the book 5

Sociological theories 6

Note 9

CHAPTER ONE

An Exploration of Sociological Concepts 10

$\begin{array}{ll}\text { Sociological perspectives } & 10\end{array}$

$\begin{array}{ll}\text { Positivism } & 10\end{array}$

Marxism $\quad 19$

Feminism $\quad 26$

Conclusions $\quad 47$

Notes $\quad 48$

\section{CHAPTER TWO}

Sociological Social Work 49

The role of social work in society $\quad 50$

The sociological project 55

Conceptual sociological frameworks 59

Social work as an object of sociological analysis $\quad 68$

$\begin{array}{ll}\text { Social work as a state activity } & 70\end{array}$

Sociological social work: a model for empowering practice $\quad 81$

Conclusions 


\section{CHAPTER THREE}

\section{A Sociology of Social Work and Feminist}

Sociological Social Work

Feminist conceptual frameworks and analyses of social work 87

Feminist sociological social work

Working with men

Conclusions

\section{CHAPTER FOUR}

The Institutional Parameters of Social Work

Social work: a state dependent profession

Gendered and racially stratified management relations

Social work within the larger societal context

Conclusions

\section{CHAPTER FIVE}

Care and Control Dynamics in Caring Relationships 138

Reinforcing oppression through social work

intervention

Enabling relationships 148

Conclusions

\section{CHAPTER SIX}

Professionalism and Training

Elitism versus democratism in a profession

A discipline with a specific remit

Professional power

Attacking anti-oppressive stances in social work 162

'Contract government' and social work 170

Conclusions

\section{CHAPTER SEVEN}

Education or Training? Power Struggles for the Heart of a Profession

Education, training or both?

The socialisation of social workers

Accrediting practice teaching

Assessment as part of the socialisation process 


\section{CHAPTER EIGHT}

Professionalism, Working Relations and

Service Delivery

Worker-'client' relationships

196

Working relations under state welfare

202

Men and the welfare state

Organising the bureau-professionals

Conclusions

\section{CHAPTER NINE}

Strategies for Change

Empowerment in worker-'client' relationships

Quality control

228

Conclusions

\section{CHAPTER TEN}

Conclusions: Sociological Social Work as a Model for Practice

Sociological social work - a 'new paradigm'

Conclusions

Bibliography

Index

275

Author Index 


\section{Acknowledgements}

Writing a book draws on the ideas, observations, philosophies and life experiences of many. Every encounter I have had has shaped the way I perceive the world, making it difficult to acknowledge all those who have assisted me in the process. I am grateful to all of you for sharing your knowledge with me in the hopes that I would both speak your truths and become wiser. I would want to identify the students and kind workers who let me watch them struggle with difficult dilemmas, facilitate the empowerment of others, laugh with them in joy at their successes and weep with them over their failures. But this is not possible. Nonetheless, you know who you are and whether I have approximated your visions for social work.

More specifically, I would want to mention the readers who gave me their comments and insights. They have made me ask myself probing questions in responding to their views. In particular, I would like to thank my colleagues, David Phillips, Tim Robinson and Glynis Jones for their helpful criticisms. Also, I am grateful to Sue Boldock for her secretarial assistance.

To my family, especially my mother and father, I owe thanks for providing the loving care that freed up my time to work on this book day and night. Finally, to David and Nicholas, I express my humblest appreciation of their good humour in surviving without me for months on end while I got on with writing. This is not a new experience for them, but they do live in hope that, someday, I will have time to participate more fully in mundane activities that mean a lot to us.

Lena Dominelli 